УДК 75/046; 51-78; 338.552

В.В. ІНДУТНИЙ, О.Г. ЗОЛОТАРЬОВА

Київський національний торговельно-економічний університет

О.Б. ПОХОДЯЩА

Національний музей історії України

\title{
ТОВАРОЗНАВЧА ОЦІНКА ТА ПРОГНОЗУВАННЯ ВАРТОСТІ ІКОН
}

\section{INDUTNYI, O. ZOLOTAROVA}

Kyiv national university of trade and economics

O. POKHODIASHCHA

National museum of the history of Ukraine

\section{COMMODITY EVALUATION AND ICON VALUES FORECASTING}

\section{https://doi.org/10.36910/6775-2310-5283-2021-14-18}

Мета. Опис одного з можливих способів оцінки якості та прогнозування вартості іконописних творів, а також опис прикладів такої оцінки, які $є$ обтрунтованими результатами досліджень стану ринку відповідних товарів.

Методика. Для досягнення поставленої мети були використані методи протокольного порівняльного аналізу зразків, щзо підлягають оцінці, з окремими об'єктами, виділеними в системі споріднених об'єктів, які вже очінені та представлені на відкритому ринку. Таким чином, досягаються вимоги щодо обтрунтованості, відтворюваності та доступності для верифікації результатів прогнозування, а також їх корекиії при наявності змін на антикварному та мистецькому ринках.

Результати. За результатами досліджень встановлено, щзо в основі формування уявлень про якість лежать гуманітарні потреби особистості в справлянні соиіокультурних обрядів «причастя-відлучення» та «обдаровування-віддаровування». Водночас, в основі формування цінових покажчиків на ринку, головне значення відіграють фінансові можливості потенційного покупия. Номенклатурне визначення якості ікон встановлюється на основі врахування сукупності корисної інформачї про них, яку обліковують за допомогою відповідей на критеріальні запитання, описані в спеціальному протоколі. Прогнозовані показники вартості ікон потрібні для визначення можливих фінансових збитків у разі втрати пам'ятки культури або наявності майнових спорів; як орієнтовні показники можливої ринкової вартості (за умови наявності попиту) або показники в фінансових операціях - страхові суми, вартість застави, вартість оренди та інше. Прогнозування вартості не можна здійснювати за кінцевими результатами аукціонних торгів споріднених предметів, адже у иьому випадку рефлекторно враховується невмотивована компонента, 
пов'язана з індивідуальними суб'єктивними потребами покупців. За участі в аукціонних торгах важливим фактором успіху слід вважати швидкий вихід предмета до рівня першої кваліметричної точки. Активність учасників ринку в цььому інтервалі дозволяє більш трунтовно передбачити результати у межах периа-друга кваліметрична точка.

Наукова новизна. Розроблено оптимальну за часом виконання методику прогнозування вартості ікон для задоволення потреб професійних очінювачів в завданнях визначення рівня фінансових збитків в результаті втрати пам'ятки культури (або часткової втрати), обтрунтування страхових сум, облікової вартості, очікуваних вартісних показників при продажу на вільному ринку, а також в операціях оренди, застави, оцінки безхазяйного майна.

Практична значимість. Проведено дослідження сучасного ринку ікон, виділено основні чинники формування уявлень про їх якість та розроблено теоретичні товарознавчі засади для здійснення оцінки якості та прогнозування вартості. Зазначені розробки мають високе практичне значення: сприятимуть збереженню иієї групи художніх та історичних пам'яток й впровадженню відповідних знань в сферу культури, національного виховання й освіти.

Ключові слова: іконопис, ікона, прогнозована вартість, показник ліквідності.

Постановка проблеми у загальному вигляді i iї зв'язок 3 важливими науковими та практичними завданнями. Багатовікова історія іконопису $\epsilon$ невід’ємною частиною національних культур багатьох народів, яка тісно пов'язана не тільки з релігійною традицією, а й розвитком мистецтва в цілому, змінами світоглядних доктрин суспільства, технічними досягненнями, діяльністю видатних художників та їх послідовників, стародавніми й новими храмами, а також важливими історичними подіями. Водночас, на них майже не відбиваються швидкоплинні зміни світських традицій. Їх тематика й спосіб використання в парадигмі релігійного культу i повсякденного життя, залишилися майже незмінними.

Важливою особливістю іконопису є обмеженість сюжетів й неосяжність способів їх матеріалізації у вигляді живопису, іконописанні по дереву, різьбленні, скульптури, графіки - усіх технічних можливостей образотворчого мистецтва. Крім того, для ікон притаманні окремі традиції оздоблення, які безпосередньо вказують на їх походження та практичне використання наявність орнаментів, підписів, особливості розмірів та пропорцій. У цих деталях знаходимо їх відмінність від світських мистецьких творів; бачимо ознаки дотримання уставлених у віках канонів написання, маємо можливість пояснити призначення - весільні, храмові, хатні. Не дивлячись на сакральність, ікони з сивої давнини присутні на усіх ринках, де існує відповідний запит 
споживачів, тому важливим $\epsilon$ дослідження факторів, що впливають на показники якості, спосіб просування на ринках та засади прогнозування вартості (пошуки обгрунтованих показників очікуваної вартості) ${ }^{[1]}$. 3'ясування цих питань є актуальним і має високу практичну значимість для професійних оцінювачів майна, діяльність яких необхідна при передачі прав власності, встановленні страхових сум, оцінки збитків власників та інше.

Аналіз останніх досліджень, у яких започатковано вирішення проблеми. Наукова атрибуція іконописних творів та вивчення іконопису як окремого виду мистецтва є важливою складовою частиною досліджень у сфері сучасного мистецтвознавства ${ }^{[2-4]}$, предметом для товарознавчих досліджень ринку, а також ланкою яка поєднує академічне та народне мистецтво.

Завдяки напрацюванням українських дослідників за роки незалежності України було створено інформативну базу відповідних наукових та популярних публікацій про осередки виробництва та стилістичні особливості української ікони Київщини, Галичини, Волині, Полісся, Наддніпрянщини, Слобожанщини та ін. ${ }^{[5-10]}$. Вже укладені й набули визнання великі приватні колекції (В.Пінчука, I.Паламарчука). Ікона широко представлена в музейних експозиціях та на антикварному ринку України й світу.

Цілі статті. Метою нашої роботи є опис одного 3 можливих способів оцінки якості та прогнозування вартості іконописних творів, а також опис прикладів такої оцінки, які є обгрунтованими результатами досліджень стану ринку відповідних товарів. Спосіб досягнення поставленої мети полягає у проведенні протокольного порівняльного аналізу зразків, що підлягають оцінці, 3 окремими об'єктами, виділеними в системі споріднених об'єктів, які вже оцінені та представлені на відкритому ринку. Таким чином, досягаються вимоги щодо обгрунтованості, відтворюваності та доступності для верифікації результатів прогнозування, a також їх корекції при наявності змін на антикварному та мистецькому ринках.

Виклад основного матеріалу дослідження 3 повним обгрунтуванням отриманих наукових результатів. Ікони можуть бути тиражованими й авторськими, вони виготовляються з урахуванням складних умов зберігання, пов’язаних з дією факторів підвищеної вологості, наявністю біологічних та хімічних впливів навколишнього середовища.

Вивчення історії та технологічних особливостей виготовлення ікон в Україні, які створювалися на чисельних мануфактурах протягом XIX та 
початку XX століть, доводить їі універсальність як джерела важливої інформації про побут, світогляд і культуру українського народу в цілому. Упредметнені в іконах символи мають соціально генеруюче, загальне виховне та естетичне значення, що в решті-решт пояснює привабливість їх як товару.

Відзначимо, що ікони $\epsilon$, передусім, засобом задоволення гуманітарних потреб особистості у їі причетності до українських культурних традицій, що передавалися в родинах 3 покоління в покоління; вони вирізняються доступністю для пересічного споживача й, водночас, характеризуються високою виразністю в утилітарному використанні, наприклад, у якості домашньої реліквії, оберегу, сакрального образу, яким благословляли на вінчання, в дорогу, просили заступництво від хвороб (образ «Покрови Пресвятої Богородиці», «Святий Миколай!, «Святий Пантелеймон»).

Маємо також зазначити, що сучасні глобалізовані ринки й, особливо, Інтернет аукціони, суттєво розширили доступ та можливості до інформації про традиції народів у виготовленні ікон, а також, що особливо важливо, створили належні умови для уніфікації товарознавчих підходів до визначення їх якості й прогнозування вартості.

Відтак, дослідження сучасного ринку ікон, виділення основних чинників формування уявлень про їх якість та розробка теоретичних товарознавчих засад для здійснення оцінки якості та прогнозування вартості, $\epsilon$ актуальним завданням, яке має практичне значення, сприяє збереженню цієї групи художніх та історичних пам'яток й впровадженню відповідних знань в сферу культури, національного виховання й освіти.

В цій роботі ми ставили перед собою завдання проаналізувати стан сучасного ринку ікон, представлених на продаж в режимі Інтернет торгів, а також на окремих сайтах галерей та іконописних майстерень. Нині це найбільш поширене та популярне джерело інформації, на яке посилаються усі учасники ринку. Важливим та актуальним завданням є також розробка оптимальної за часом виконання методики прогнозування вартості ікон для задоволення потреб професійних оцінювачів в завданнях визначення рівня фінансових збитків в результаті втрати пам'ятки культури (або часткової втрати), обгрунтування страхових сум, облікової вартості, очікуваних вартісних показників при продажу на вільному ринку, а також в операціях оренди, застави, оцінки безхазяйного майна.

Для вирішення поставлених проблем, була створена база вихідних даних, яка являє собою таблицю, де послідовно - в порядку зростання питомої 
вартості - вибрана 131 ікона. Питома вартість визначається показником співвідношення вартості у гривнях до площі ікони в квадратних дециметрах. Усі виставлені на продаж ікони, на момент укладення таблиці (20.03.2020p.), знаходилися в стані торгів, тобто поступового зростання вартості пропонованої власником. Відтак, укладена таким чином таблиця вихідної інформації віддзеркалює лише функцію зростання вартості й не може використовуватися як звичайний прейскурант для проведення порівняльного аналізу, адже на момент продажу останній показник ціни не співпадає із зафіксованим у цій таблиці поточним (є значно меншим) й $\epsilon$ нам невідомим. Водночас, ми неодноразово наголошували на тому, що функція приросту вартості описується у відповідності з законом товарознавства: «Чим більше позитивної інформації про товар, тим вища його якість й, відповідно вартість» [11].

Досліджуючи функцію приросту вартості, ми з'ясовуємо наявність та вид функціональної відповідності уявлень про якість до поточної вартості й, таким чином (на основі цієї відповідності) вирішуємо питання прогнозування вартості антикварних предметів і, зокрема ікон.

Так, на рисунку 1 подано перманентний розподіл показників питомої вартості (у гривнях за квадратний дециметр) у просторі вихідних даних відсортованих в порядку зростання.

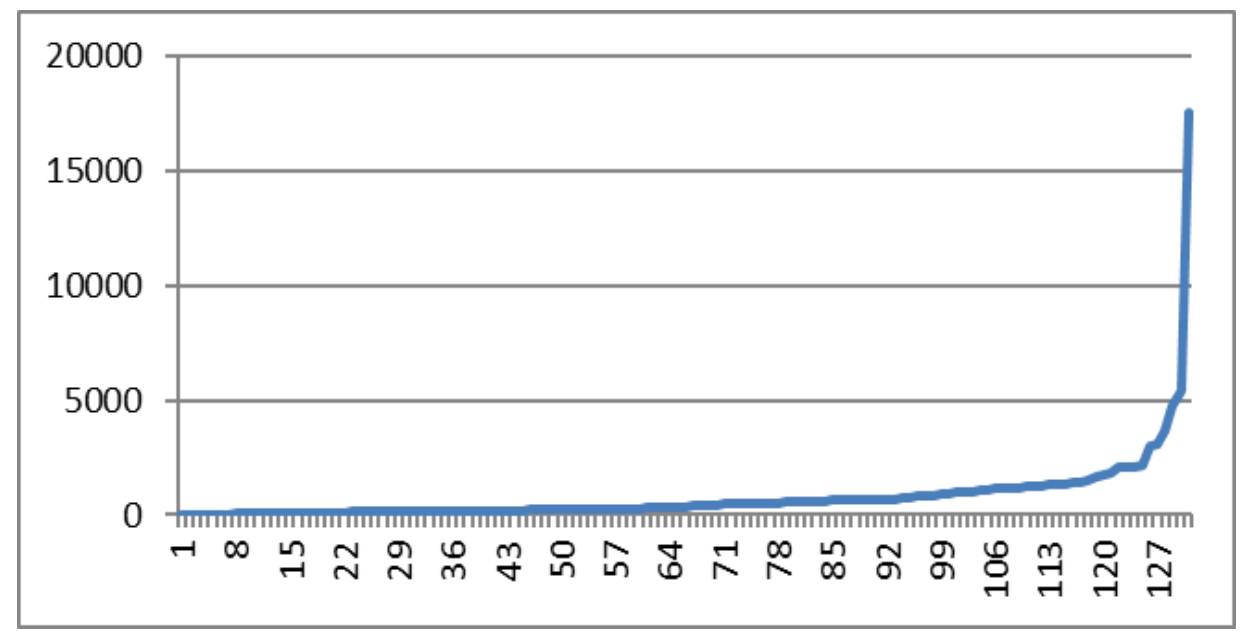

Рис. 1. Розподіл питомих показників вартості ікон, описаних таблицею вихідних даних (вісь ординат - показник питомої вартості у гривнях; вісь абсцис - порядок вартості або номер ікони в таблиці вихідних даних).

Графік вказує на досить нерівномірне за кількістю представництво взірців різних за вартісними показниками ікон на ринку й описується експоненціально - недорогих взірців на ринку представлено значно більше аніж дорогих. 
Подана вище тенденція розподілу вартісних показників спостерігається в усіх видах товарів, які представлені на антикварному ринку і пов'язана 3 тим, що вона рефлекторно описує особливості розподілу фінансових можливостей потенційних покупців, про що ми неодноразово писали ${ }^{[12-17]}$. Ліквідність товарів для задоволення гуманітарних потреб особистості, зокрема ікон, є пов'язаною з рівнем річних статків громадян, а також з відповідною ціновою пропозицією.

Аналітичні розвідки про предмет надають нам можливість здійснювати перевірку гіпотези про те, що чим більше позитивної інформації про товар, тим вище його якість i, відповідно, вартість. Нагадаємо, що загальне формулювання гіпотези є таким:

$$
\mathrm{C}=\propto \times 2^{\mathrm{i}}
$$

де $\quad$ i - кількість позитивної інформації про товар у бітах;

$\propto$ - база оцінки

Отже, щоб перевірити цю гіпотезу, а також дослідити характер цієї відповідності, здійснимо логарифмування питомих показників вартості за основою 2 та побудуємо відповідний графік (рис. 2).

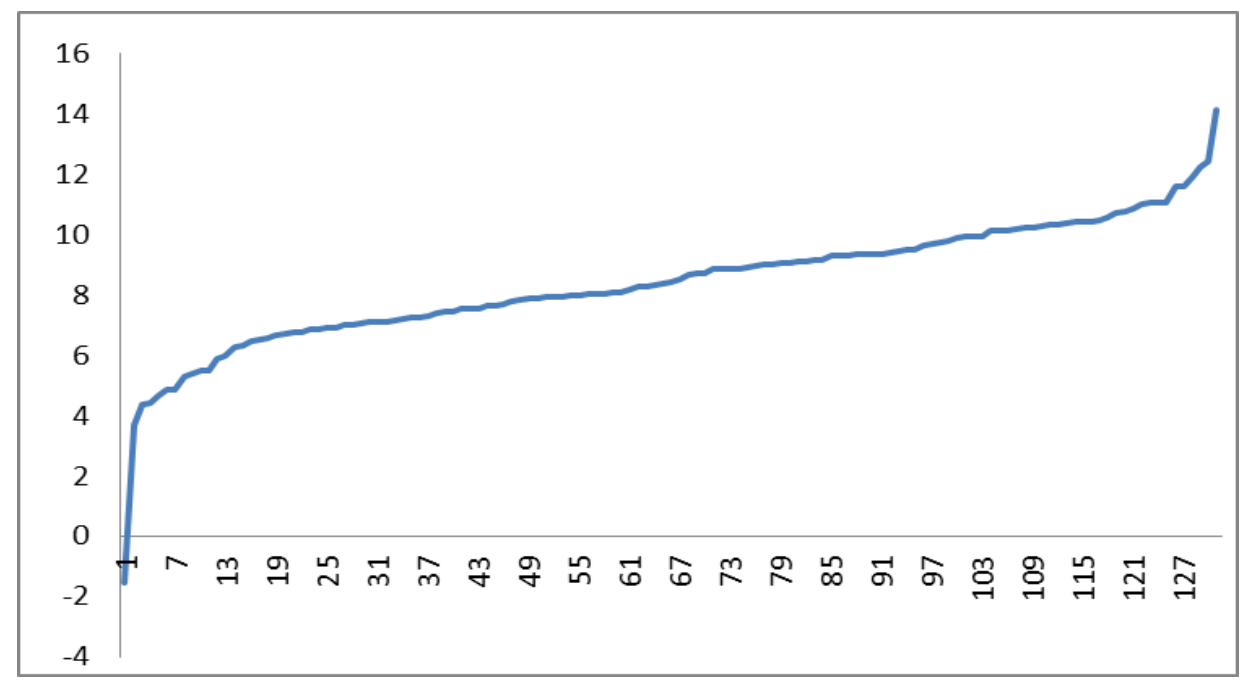

Рис.2. Розподіл логарифмованих за основою «2» питомих показників вартості, ікон описаних таблицею вихідних даних (вісь ординат - логарифмовані за основою «2» питомі показники вартості ікон; вісь абсцис - порядок вартості або номер ікони в таблиці вихідних даних) 
На графіку, поданому на рисунку 2 видно, що увесь діапазон питомих вартісних показників на ікони можна розділити на три інтервали (виділені червоними вертикальними лініями на графіку 2) - товарознавчі групи - які відрізняються за тенденцією зростання питомих показників: Перша - це ікони від першої до чотирнадцятої з вартісними питомими показниками відповідно від 1 до 75 гривень за дециметр квадратний поверхні; друга - іконописні твори від 14 до 118 номера 3 показниками вартості від 75 до 1500 гривень за дециметр квадратний; третя - ікони від 119 до 125 номера 3 питомими показниками показниками вартості від 1500 до 5500 гривень за дециметр квадратний поверхні. Причому, остання ікона характеризується аномально високим показником питомої вартості, який, вочевидь, не може бути поясненим на основі спостереженої тенденції, тому ця ікона повинна бути елімінованою 3 досліджуваної сукупності взірців.

Перша група описує ті ікони, які щойно виставлені на продаж i, відповідно, для залучення більшої кількості учасників торгів, для них встановлюють змістовно невмотивовані аномально низькі стартові показники вартості (наприклад, одна гривня), які, зрозуміло, є значно нижчими від тих рівнів, на яких знаходиться основна маса творів і які вже придбані. Тобто, в цьому інтервалі торги не припиняються, зацікавлених учасників торгів багато, адже потенційні покупці завжди готові платити за цей товар значно більші суми. Тенденція, звичайно, може бути аналітично описаною за допомогою асимптотичної формули (2) - функції насичення:

$$
C=75 \times\left(1-2^{(1-i)}\right)
$$

де $\quad$ i - кількість дефіцитарної інформації про товар; 75 - показник базової питомої вартості (гривні за дециметр квадратний) на графіку поданому на рисунку 2, в точці, де тенденція до зростання повністю змінюється (перша червона лінія). Цей показник може також вважатися базою оцінки для наступної групи взірців.

Описану вище та аналітично визначену тенденцію, яка пов'язує якість товару з його вартістю, недоцільно використовувати в практиці прогнозування, крім випадків визначення мінімальних рівнів ліквідаційної вартості, оскільки в цьому інтервалі питомих показників відсутні ознаки врахування потенційним покупцем якісних параметрів товару. Існує лише його бажання придбати твір; він вважає заявлену вартість аномально низькою й продовжує участь в торгах. 
Друга група - це ікони, для яких спостерігається чітке виконання вище згаданої гіпотези, адже в логарифмованій за основою «2» шкалі питомих вартісних показників, тенденція описується лінійно (адитивне збільшення позитивної інформації) й у повній відповідності 3 формульним виразом гіпотези. Це, зокрема, підтверджує те, що вартісні показники, які ми бачимо в цьому інтервалі, є обгрунтованими якісними характеристиками і прогнозування вартості на основі апроксимуючих лінійних функцій є цілком виправданим.

Важливо звернути увагу на «точку переходу» питомих вартісних показників, які ми віднесли до першої групи (перша червона лінія на графіку 2), до питомих вартісних показників, віднесених до другої групи, яка визначається на рівні 75 гривень.

Це особлива точка, яка позначена різкою зміною градієнта зростання та зміною виду апроксимуючої функції зростання, яка описується в другому інтервалі формулою (3):

$$
\mathrm{C}=75 \times 2^{\mathrm{i}}
$$

де і - кількість позитивної інформації про товар; 75 - база оцінки

3 поданої вище формули (2) видно, що йшлося про формальну недостачу або свідоме ігнорування певним обсягом позитивної інформації про товар на стадії його представлення на ринку, що можна також тлумачити як наявність негативної (контраверсійної або дефіцитарної) інформації. В другому інтервалі (за першою червоною лінією на графіку 2), де тенденція до зростання описується формулою (3), вартісні показники вже досягли позначки 75 гривень, тому цю позначку слід вважати емпіричною базою для прогнозної оцінки в межах другого інтервалу. Цей показник вартості фігурує як особлива перехідна точка, яку ми повинні називати також «першою кваліметричною точкою», тобто точкою де вперше приймаються до уваги об'єктивні показники якості товару й наступає етап предметної (аргументованої) конкуренції між потенційними покупцями 3 використанням супровідної атрибутивної інформації.

Формула (3) описує тенденцію до зростання вартісних показників у другому інтервалі. Відповідно, інтервал закінчується там, де знову змінюється спостережена тенденція до зростання (друга червона лінія на графіку 2). Раніше ми встановили, що графіки розподілу вартісних показників різних видів 
антикварних товарів приводять до висновку про те, що така перехідна точка існує на усіх логарифмованих графіках розподілу вартісних показників пойменованих вище видів товарів. Наявність «першої кваліметричної точки» на відповідних графіках має, на нашу думку, лише одне раціональне пояснення розподіл вартісних показників на ринку віддзеркалює розподіл фінансових можливостей потенційних покупців [6].

Отже, «перша кваліметрична точка» - це загальна обгрунтована база оцінки для ікон, які мають визначені споживчі якості в другій групі (рис.2).

Сказане дозволяє твердити, що в суспільстві існують і системно, разом 3 економікою та культурою, розвиваються універсальні уявлення про еквіваленти цінності, які в певних співвідношеннях збігаються з уявленнями про цінність тієї чи іншої грошової одиниці. Такий збіг в гуманітарному просторі та на інтуїтивному рівні $\epsilon$ важливим фактором формування уявлень про рівень задоволення гуманітарних потреб релевантний до рівня понесених збитків.

У свою чергу, це дозволяє оцінювачам уніфікувати процес прогнозування вартості пам'яток культури в завданнях визначення рівня збитків власника або національної культури у разі їх втрати або пошкодження. Тобто, існує економічно та соціально обгрунтована можливість проектування та впровадження на державному рівні індикативних показників вартості на пам'ятки культури для вирішення широкого спектру завдань оцінки, які мають загальнодержавне значення. Особливо маємо звернути увагу на появу в сучасному світі нових можливостей використання пам'яток культури, які знаходяться у комунальній власності або власності фізичних осіб, у фінансових операціях, у тому числі на основі криптовалют. Останнє вже має місце в багатьох країнах світу.

Повертаючись до обговорення графіка, поданого на рисунку 2, розглянемо третю групу ікон, яка виділяється досить високими показниками вартості. Це відносно невелика кількість творів, де продавці користуються підвищеними споживчими потребами частини найбільш заможних потенційних покупців, їх часто необгрунтованими емоційними бажаннями, i свідомо завищують вартісні показники. Відповідно мають місце невмотивовані надбавки, а також виникають нові можливості для загострення конкурентної аукціонної торгівлі. Тенденція до зростання апроксимаційної функції знову змінюється й, відповідно, виникає потреба виділення «другої кваліметричної точки», яка визначає необхідність використання нової асимптотичної функції, такого вигляду: 


$$
\mathrm{C}=\alpha \times 2^{\mathrm{i}} \times 2^{\mathrm{x}} \text { або } \mathrm{C}=\alpha \times 2^{(\mathrm{i}+\mathrm{x})}
$$

де $\quad \mathrm{i}-$ кількість позитивної інформації про товар; $\propto$ - база оцінки;

x - кількість додаткової невмотивованої інформації .

Беручи до уваги те, що невмотивовані надбавки не можуть бути врахованими оцінювачами та експертами перманентно (наприклад, при наявності інформації про двох і більше претендентів на покупку), передбачити результат проведення торгів неможливо. Кінцевий результат торгів $€$ невмотивованим, не підлягає змістовному поясненню та не може використовуватися як орієнтир в оціночній справі Так, наприклад, не має сенсу посилатися на результати торгів відомих у всьому світі аукціонів, адже частина прикінцевого показника вартості не піддається раціональному поясненню. Відтак, третя група, яка описується асимптотичною формулою (4) не має практичного значення в роботі експерта-оцінювача, адже результати продажу 3 аукціону, де наприкінці торгів можуть мати місце невмотивовані рішення, взагалі не можуть бути предметом прогнозування.

Отже, знову дійдемо висновку про те, що найбільш представницькою, змістовною та цікавою для побудування асимптотичних моделей, які описують вартість антикварних виробів та ікон, $є$ друга товарознавча група.

Відповідно, тенденція до зростання питомих показників вартості в логарифмованому вигляді може бути описаною асимптотичною лінійною функцією, параметри якої знаходимо за допомогою методу найменших квадратичних відхилень К.Ф.Гауса [18].

Після перетворення на основі ступеневої функції за основою «2», ця функція матиме такий вигляд (рис. 3):

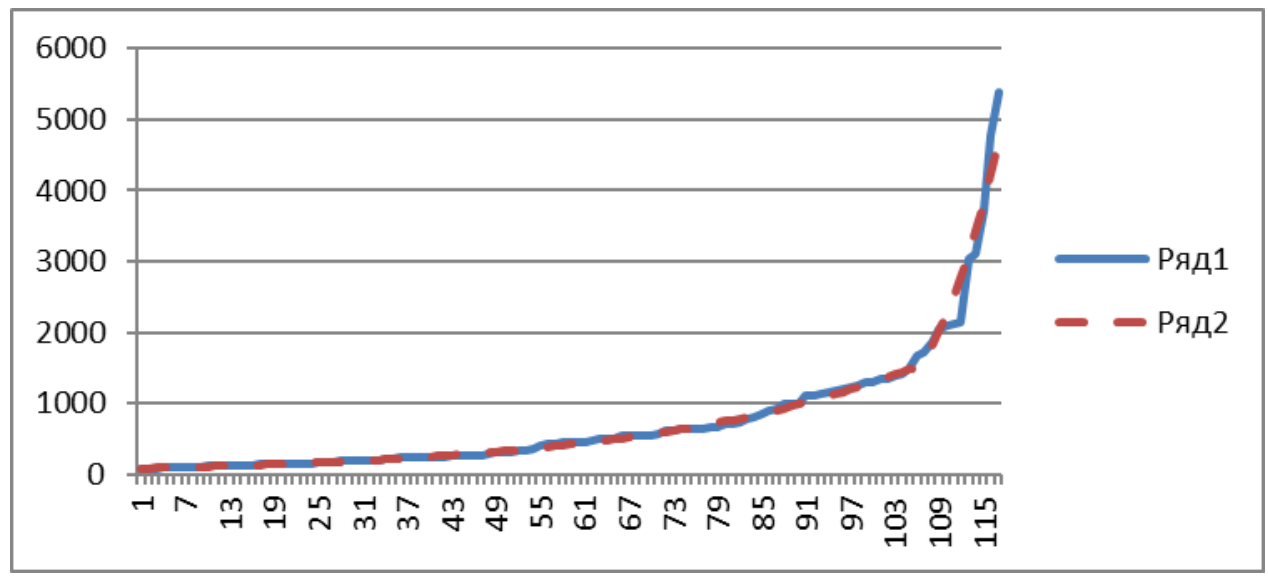

Рис 3. Співвідношення між спостереженими показниками питомої вартості ікон (ряд 1), у гривнях за дециметр квадратний, та теоретично обрахованими питомими показниками (ряд 2) з урахуванням виявлених тенденцій до зростання 
В результаті проведених досліджень ми з'ясували, що прогнозування питомих показників вартості ікон слід здійснювати за емпіричною формулою:

$$
\mathrm{C}=2^{0,04 \mathrm{x}+5,84}
$$

де $\mathrm{C}$ - прогнозований показник питомої вартості ікон,

$\mathrm{x}$ - порядок вартості (номер твору в таблиці вихідних даних, які можуть використовуватися у якості еталонів).

Показник якості апроксимації спостереженої тенденції за К.Пірсоном 0,98 .

Описане регресійне рівняння можна також представити таким чином:

$$
\mathrm{C}=2^{0,04 \mathrm{x}+5,84}=2^{0,04} \times 2^{5,84}=57,28 \times 2^{0,04 \mathrm{x}}
$$

Бачимо, що описана нами емпірична формула дуже нагадує формулювання гіпотези(1), однак, відрізняється тим, що величина « $2^{0,04 x}$ » пов'язує величину прогнозованої питомої вартості з порядком вартості «Х», а не $з$ величиною кількості позитивної інформації про об'єкт дослідження.

Для того, щоб перейти до розрахунків величини прогнозованого показника питомої вартості з урахуванням показника кількості позитивної інформації, будемо вважати, що перший вартісний покажчик, який має змістовне пояснення і відповідає за рівень одного біту інформації, отже, має місце рівняння $2^{0,04 x}=1$, тобто це «особлива» точка переходу від необгрунтованих показників до змістовно обгрунтованих - «перша кваліметрична точка». Зрозуміло, що в цьому рівнянні, якщо $\mathrm{x}=0$, це означає, що позитивна інформації про товар складає 1 біт, і скоріше за усе вона ігнорується потенційним покупцем. Величина $\mathrm{C}=57,28$ гривень за дециметр квадратний вказує на необхідність використання цього показника у якості розрахункової бази для оцінки ікон й, у подальшому, використовувати іiі в завданнях прогнозування вартості у межах усього інтервалу описаного другою групою:

$$
\mathrm{C}=57,28 \times 2^{\mathrm{i}} \times \mathrm{S}
$$

де $\mathrm{S}$ - площа ікони в дециметрах квадратних.

Отже, прогнозування вартості ікон нині може здійснюватися за представленою вище формулою. Враховуючи динаміку змін цінових показників 
на ринку перерахунки слід здійснювати не частіше ніж раз на рік. При цьому, для здійснення обліку позитивної інформації та обрахування їі кількості - при «i $=0,1,2, \ldots »-$ ми використовуємо спеціальний протокол (таблиця 1), в якому добуток усіх показників «N» дорівнює величині « $2^{\mathrm{i}} »[11]$. В протокол внесені дані першого приклада оцінки ікони, опис якої наведений нижче. Однак слід зауважити, що на практиці - при оцінці ікон - в поданому нижче протоколі враховують не увесь перелік критеріїв, а лише ті, які відповідають їх видовій специфіці. Це пов'язується з тим, що впродовж багатьох років сформувалися та набули загального визнання традиції оцінки пам’яток культури за окремими скороченими переліками критеріїв.

Таблиця 1. Протокол для обліку кількості позитивної інформації про пам’ятку культури на основі індексу соціокультурної значимості «N»

\begin{tabular}{|c|c|c|c|c|}
\hline $\begin{array}{l}\text { № } \\
3 / \Pi\end{array}$ & $\begin{array}{c}\text { Назва оціночного } \\
\text { критерію }\end{array}$ & $\begin{array}{c}\text { Ранжування } \\
\text { оціночного критерію } \\
\text { і коефіцієнт «n } \text { (під- }^{+} \\
\text {креслити необхідне) }\end{array}$ & $\begin{array}{c}\text { Ранжування контраверсійного оціночного } \\
\text { критерію і зменшуючий коефіцієнт «n } \\
\text { (підкреслити необхідне) }\end{array}$ & $\begin{array}{l}\text { Peз. } \\
\text { Koeф. } \\
\quad \mathrm{N} \\
=\mathrm{n}^{+} \times \mathrm{n}^{-}\end{array}$ \\
\hline 1 & 2 & 3 & 4 & 5 \\
\hline \multirow[t]{3}{*}{1.} & \multirow{3}{*}{$\begin{array}{l}\text { Історія побуту- } \\
\text { вання пам'ятки } \\
\text { (онтологія) }\end{array}$} & Невідома (1) & \multirow{3}{*}{$\begin{array}{l}\text { Відома або невідома, але не передбачає } \\
\text { використання критерію (1) } \\
\text { Інформація потрібна, але підтверджується } \\
\text { частково }(0,5) \\
\text { Інформація потрібна, але невідома або не } \\
\text { підтверджується }(0,25)\end{array}$} & \multirow[t]{3}{*}{1} \\
\hline & & Частково відома (2) & & \\
\hline & & Повністю відома (4) & & \\
\hline \multirow[t]{7}{*}{2} & \multirow[t]{7}{*}{ Вік пам’ятки } & Невідомий (1) & \multirow{7}{*}{$\begin{array}{l}\text { Відомий або невідомий, але не передбачає } \\
\text { використання } \\
\text { критерію }(1) \\
\text { Інформація потрібна, але підтверджується } \\
\text { частково }(0,5) \\
\text { Інформація має визначальне значення, але } \\
\text { невідома або не підтверджується }(0,25)\end{array}$} & \multirow[t]{7}{*}{4} \\
\hline & & До 50 років (1) & & \\
\hline & & До 100 років (2) & & \\
\hline & & До 300 років (4) & & \\
\hline & & До 1000 років (8) & & \\
\hline & & До 2000 років (16) & & \\
\hline & & $\begin{array}{l}\text { Більше } 2000 \text { років } \\
\text { (32) }\end{array}$ & & \\
\hline \multirow[t]{3}{*}{3.} & \multirow[t]{3}{*}{$\begin{array}{l}\text { Тиражованість } \\
\text { пам’ятки }\end{array}$} & $\begin{array}{l}\text { Тиражована (типова) } \\
\text { (1) }\end{array}$ & \multirow{3}{*}{$\begin{array}{l}\text { Відома або невідома, але не передбачає } \\
\text { використання критерію (1) } \\
\text { Інформація потрібна, але підтверджується } \\
\text { частково }(0,5) \\
\text { Інформація потрібна, але невідома або не } \\
\text { підтверджується }(0,25)\end{array}$} & \multirow[t]{3}{*}{2} \\
\hline & & Рідкісна (2) & & \\
\hline & & Унікальна (4) & & \\
\hline \multirow[t]{3}{*}{4.} & \multirow[t]{3}{*}{$\begin{array}{l}\text { Рівень визнання } \\
\text { пам’ятки }\end{array}$} & $\begin{array}{l}\text { Місцевого значення } \\
\text { або не набув } \\
\text { визнання (1) }\end{array}$ & \multirow{3}{*}{$\begin{array}{l}\text { Відомий або невідомий, але не передбачає } \\
\text { використання критерію (1) } \\
\text { Інформація потрібна, але підтверджується } \\
\text { частково }(0,5) \\
\text { Інформація потрібна, але невідома або не } \\
\text { підтверджується }(0,25)\end{array}$} & \multirow[t]{3}{*}{1} \\
\hline & & $\begin{array}{l}\text { Національного } \\
\text { значення (2) }\end{array}$ & & \\
\hline & & $\begin{array}{l}\text { Світового значення } \\
\text { (4) }\end{array}$ & & \\
\hline \multirow[t]{3}{*}{5.} & \multirow{3}{*}{$\begin{array}{l}\text { Причетність } \\
\text { пам'ятки до } \\
\text { культурних } \\
\text { традицій }\end{array}$} & $\begin{array}{l}\text { Місцеві й родові } \\
\text { традиції (1) }\end{array}$ & \multirow{3}{*}{$\begin{array}{l}\text { Відома або невідома, але не передбачає } \\
\text { використання критерію }(1) \\
\text { Інформація потрібна, але підтверджується } \\
\text { частково }(0,5) \\
\text { Інформація потрібна, але невідома або не } \\
\text { підтверджується }(0,25)\end{array}$} & \multirow[t]{3}{*}{2} \\
\hline & & $\begin{array}{l}\text { Національні традиції } \\
(2)\end{array}$ & & \\
\hline & & Світові традиції (4) & & \\
\hline
\end{tabular}


Товарознавчий вісник. - 2021. - Випуск 14.

\begin{tabular}{|c|c|c|c|c|}
\hline 1 & 2 & 3 & $\underline{4}$ & 5 \\
\hline \multirow[t]{3}{*}{6.} & \multirow[t]{3}{*}{$\begin{array}{l}\text { Рівень визнання } \\
\text { автора пам'ятки }\end{array}$} & $\begin{array}{l}\text { Місцевого значення } \\
\text { або не набув } \\
\text { визнання (1) }\end{array}$ & \multirow{3}{*}{$\begin{array}{l}\text { Відомий або невідомий, але не передбачає } \\
\text { використання критерію (1) } \\
\text { Інформація потрібна, але підтверджується } \\
\text { частково }(0,5) \\
\text { Інформація потрібна, але невідома або } \\
\text { не підтверджується }(0,25)\end{array}$} & \multirow[t]{3}{*}{1} \\
\hline & & $\begin{array}{l}\text { Національного } \\
\text { значення (2) }\end{array}$ & & \\
\hline & & $\begin{array}{l}\text { Світового значення } \\
\text { (4) }\end{array}$ & & \\
\hline \multirow[t]{3}{*}{7.} & \multirow{3}{*}{$\begin{array}{l}\text { Причетність } \\
\text { пам’ятки до } \\
\text { історичних подій }\end{array}$} & $\begin{array}{l}\text { Місцевого значення } \\
\text { або непричетна (1) }\end{array}$ & \multirow{3}{*}{$\begin{array}{l}\text { Відома або невідома, але не передбачає } \\
\text { використання критерію (1) } \\
\text { Інформація потрібна, але підтверджується } \\
\text { частково }(0,5) \\
\text { Інформація потрібна, але невідома або } \\
\text { не підтверджується }(0,25)\end{array}$} & \multirow[t]{3}{*}{1} \\
\hline & & $\begin{array}{l}\text { Національного } \\
\text { значення (2) }\end{array}$ & & \\
\hline & & $\begin{array}{l}\text { Світового значення } \\
\text { (4) }\end{array}$ & & \\
\hline \multirow[t]{3}{*}{8.} & \multirow{3}{*}{$\begin{array}{l}\text { Причетність } \\
\text { пам’ятки до інших } \\
\text { пам’яток історії та } \\
\text { культури }\end{array}$} & $\begin{array}{l}\text { Місцевого значення } \\
\text { або непричетна (1) }\end{array}$ & \multirow{3}{*}{$\begin{array}{l}\text { Відома або невідома, але не передбачає } \\
\text { використання критерію (1) } \\
\text { Інформація потрібна, але підтверджується } \\
\text { частково }(0,5) \\
\text { Інформація потрібна, але невідома або } \\
\text { не підтверджується }(0,25)\end{array}$} & \multirow[t]{3}{*}{1} \\
\hline & & $\begin{array}{l}\text { Національного } \\
\text { значення (2) }\end{array}$ & & \\
\hline & & $\begin{array}{l}\text { Світового значення } \\
\text { (4) }\end{array}$ & & \\
\hline \multirow[t]{3}{*}{9.} & \multirow{3}{*}{$\begin{array}{l}\text { Причетність } \\
\text { пам’ятки до } \\
\text { видатних } \\
\text { особистостей }\end{array}$} & $\begin{array}{l}\text { Місцевого значення } \\
\text { або непричетна (1) }\end{array}$ & \multirow{3}{*}{$\begin{array}{l}\text { Відома або невідома, але не передбачає } \\
\text { використання критерію (1) } \\
\text { Інформація потрібна, але підтверджується } \\
\text { частково }(0,5) \\
\text { Інформація потрібна, але невідома або } \\
\text { не підтверджується }(0,25)\end{array}$} & \multirow[t]{3}{*}{1} \\
\hline & & $\begin{array}{l}\text { Національного } \\
\text { значення (2) }\end{array}$ & & \\
\hline & & $\begin{array}{l}\text { Світового значення } \\
\text { (4) }\end{array}$ & & \\
\hline \multirow[t]{3}{*}{10.} & \multirow{3}{*}{$\begin{array}{l}\text { Причетність } \\
\text { пам’ятки до } \\
\text { видатних } \\
\text { мануфактур і шкіл }\end{array}$} & $\begin{array}{l}\text { Місцевого значення } \\
\text { або непричетна (1) }\end{array}$ & \multirow{3}{*}{$\begin{array}{l}\text { Відома або невідома, але не передбачає } \\
\text { використання критерію (1) } \\
\text { Інформація потрібна, але підтверджується } \\
\text { частково }(0,5) \\
\text { Інформація потрібна, але невідома або } \\
\text { не підтверджується }(0,25)\end{array}$} & \multirow[t]{3}{*}{2} \\
\hline & & $\begin{array}{l}\text { Національного } \\
\text { значення (2) }\end{array}$ & & \\
\hline & & $\begin{array}{l}\text { Світового значення } \\
\text { (4) }\end{array}$ & & \\
\hline \multirow[t]{3}{*}{11.} & \multirow[t]{3}{*}{$\begin{array}{l}\text { Соціокультурна } \\
\text { функція пам’ятки }\end{array}$} & $\begin{array}{l}\text { Ужиткова або } \\
\text { декоративна (1) }\end{array}$ & \multirow{3}{*}{$\begin{array}{l}\text { Відома або невідома, але не передбачає } \\
\text { використання критерію (1) } \\
\text { Інформація потрібна, але підтверджується } \\
\text { частково }(0,5) \\
\text { Інформація потрібна, але невідома або не } \\
\text { підтверджується }(0,25)\end{array}$} & \multirow[t]{3}{*}{4} \\
\hline & & $\begin{array}{l}\text { Авторське послання } \\
\text { (2) }\end{array}$ & & \\
\hline & & Загальновиховна (4) & & \\
\hline \multirow[t]{3}{*}{12.} & \multirow{3}{*}{$\begin{array}{l}\text { Масштабність } \\
\text { творчої ідеї }\end{array}$} & Пересічна (1) & Відома або невідома, але не передбачає & \multirow[t]{3}{*}{1} \\
\hline & & Висока (2) & використання критерію (1) & \\
\hline & & Світоглядна (4) & $\begin{array}{l}\text { Інформація потрібна, але підтверджується } \\
\text { частково }(0,5) \\
\text { Інформація потрібна, але невідома або не } \\
\text { підтверджується }(0,25)\end{array}$ & \\
\hline \multirow[t]{3}{*}{13.} & \multirow[t]{3}{*}{$\begin{array}{l}\text { Наукова } \\
\text { значимість } \\
\text { пам'ятки }\end{array}$} & $\begin{array}{l}\text { Пересічна або не має } \\
\text { наукової значимості } \\
\text { (1) }\end{array}$ & \multirow{3}{*}{$\begin{array}{l}\text { Відома або невідома, але не передбачає } \\
\text { використання критерію (1) } \\
\text { Інформація потрібна, але підтверджується } \\
\text { частково }(0,5) \\
\text { Інформація потрібна, але невідома або не } \\
\text { підтверджується }(0,25)\end{array}$} & \multirow[t]{3}{*}{2} \\
\hline & & Висока (2) & & \\
\hline & & Найвища (4) & & \\
\hline \multirow[t]{3}{*}{14.} & \multirow[t]{3}{*}{$\begin{array}{l}\text { Художня цінність } \\
\text { пам'ятки }\end{array}$} & $\begin{array}{l}\text { Пересічна або не має } \\
\text { художньої цінності } \\
\text { (1) }\end{array}$ & $\begin{array}{l}\text { Відома або невідома, але не передбачає } \\
\text { використання критерію (1) } \\
\text { Інформація потрібна, але підтверджується }\end{array}$ & 2 \\
\hline & & Висока (2) & частково $(0,5)$ & \\
\hline & & Найвища (4) & $\begin{array}{l}\text { Інформація потрібна, але невідома або не } \\
\text { підтверджується }(0,25)\end{array}$ & \\
\hline
\end{tabular}


Товарознавчий вісник. - 2021. - Випуск 14.

\begin{tabular}{|c|c|c|c|c|}
\hline 1 & 2 & $\underline{3}$ & 4 & 5 \\
\hline \multirow[t]{3}{*}{15.} & \multirow{3}{*}{$\begin{array}{l}\text { Рівень технічної } \\
\text { досконалості }\end{array}$} & Пересічний (1) & \multirow[t]{3}{*}{ Недосконалий $(0,5)$} & \multirow[t]{3}{*}{1} \\
\hline & & Високий (2) & & \\
\hline & & Найвищий (4) & & \\
\hline \multirow[t]{2}{*}{16.} & \multirow{2}{*}{$\begin{array}{l}\text { Особливі якості } \\
\text { пам'ятки }\end{array}$} & Відсутні (1) & \multirow{2}{*}{$\begin{array}{l}\text { Відомі або невідомі, але не передбачають } \\
\text { використання } \quad \text { критерію (1) } \\
\text { Інформація потрібна, але підтверджуються } \\
\text { частково }(0,5)\end{array}$} & \multirow[t]{2}{*}{1} \\
\hline & & Наявні (2) & & \\
\hline \multirow[t]{3}{*}{17.} & \multirow{3}{*}{$\begin{array}{l}\text { Історико- } \\
\text { культурна } \\
\text { цінність } \\
\text { матеріалів }\end{array}$} & $\begin{array}{l}\text { Пересічні матеріали } \\
\underline{(1)}\end{array}$ & \multirow{3}{*}{$\begin{array}{l}\text { Відомі або невідомі, але не передбачають } \\
\text { використання критерію (1) } \\
\text { Інформація потрібна, але підтверджується } \\
\text { частково }(0,5) \\
\text { Інформація потрібна, але невідома або не } \\
\text { підтверджується }(0,25)\end{array}$} & \multirow[t]{3}{*}{1} \\
\hline & & Рідкісні матеріали (2) & & \\
\hline & & $\begin{array}{l}\text { Унікальні матеріали } \\
\text { (4) }\end{array}$ & & \\
\hline \multirow[t]{3}{*}{18.} & \multirow[t]{3}{*}{ Розміри пам'ятки } & E звичайними (1) & \multirow{3}{*}{$\begin{array}{l}\text { Відомі або невідомі, але не передбачають } \\
\text { використання критерію (1) } \\
\text { Інформація потрібна, але підтверджується } \\
\text { частково }(0,5) \\
\text { Інформація потрібна, але невідома або не } \\
\text { підтверджується }(0,25)\end{array}$} & \multirow[t]{3}{*}{1} \\
\hline & & $\begin{array}{l}\text { Є причиною } \\
\text { помірного збільшен- } \\
\text { ня споживчої } \\
\text { цінності (2) } \\
\end{array}$ & & \\
\hline & & $\begin{array}{l}\text { Є визначальними для } \\
\text { збільшення } \\
\text { споживчої цінності } \\
\text { (4) }\end{array}$ & & \\
\hline 19. & $\begin{array}{l}\text { Наявність знаків і } \\
\text { позначок }\end{array}$ & $\begin{array}{l}\text { Знаки і позначки } \\
\text { присутні (2) }\end{array}$ & $\begin{array}{l}\text { Відомі або невідомі, але не передбачають } \\
\text { використання критерію (1) } \\
\text { Інформація потрібна, але підтверджується } \\
\text { частково або сумнівна }(0,5) \\
\text { Відсутні }(0,25)\end{array}$ & 1 \\
\hline 20. & Комплектність & Комплектний (1) & Некомплектний $(0,5)$ & 1 \\
\hline 21. & $\begin{array}{l}\text { Стан збереження } \\
\text { пам'ятки }\end{array}$ & Без пошкоджень (1) & $\begin{array}{l}\text { Задовільний }(0,5) \\
\text { Незадовільний }(0,25) \\
\text { У фрагментах }(0,125) \\
\text { В одиничних фрагментах }(0,0625)\end{array}$ & 0,5 \\
\hline
\end{tabular}

Виходячи з результатів дослідження ринку ікон, які ми отримали на основі математичної обробки таблиці вихідних даних, а також враховуючи особливості продажу ікон на аукціонах, слід зробити висновок про можливість укладання таблиць індикаторних показників для прогнозування їх вартості у відповідності до кількості облікової інформації (таблиця 2). Звичайно, ці показники не є обов'язковими для здійснення операцій купівлі-продажу або інших операцій 3 пам'ятками культури, однак вони дозволяють визначити логічно непротирічний результат прогнозування вартості.

Отже, загальний порядок роботи експерта полягає у тому, що спочатку він, використовуючи поданий вище протокол, обліковує усю корисну інформацію i, користуючись таблицею 2, номенклатурно визначає рівень соціокультурного значення досліджуваної ікони (показник іiї якості який виражається словосполученням, наприклад: «пам'ятка культури національного рівня 
значення другого порядку»). Індикаторними ми називаємо розрахункові показники, отримані в результаті дослідження стану ринку. Далі, приймаючи до уваги загальну кількість позитивної інформації про об’єкт дослідження, прогнозує вартість у відповідності з станом сучасного ринку.

\section{Таблиця 2. Номенклатурна класифікація якості та індикаторні показники} прогнозованої вартості ікон

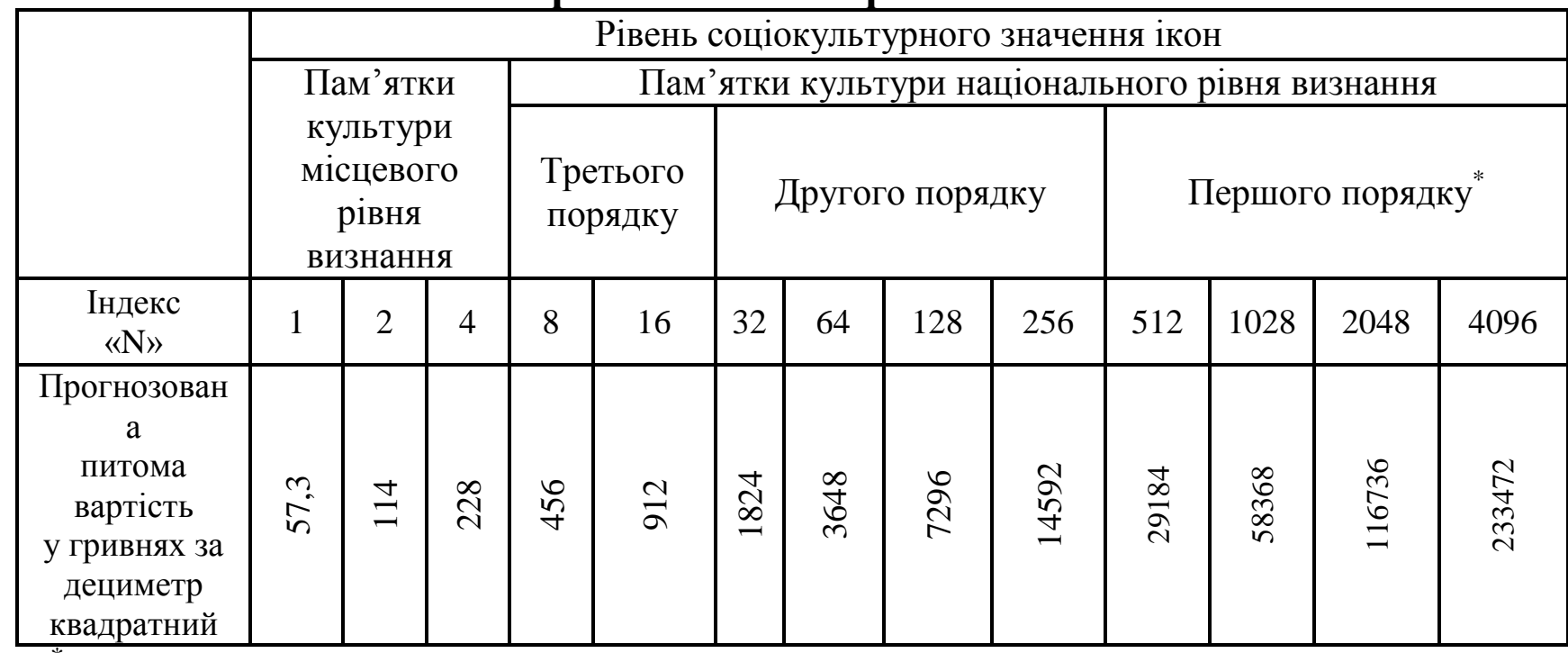

Примітка: більш високі показники індексу «N» розраховуються згідно загальної класифікації пам'яток культури поданою в ${ }^{[11]}$

Варто також зазначити, що вивчаючи тенденцію зростання питомих вартісних показників на ікони в таблиці вихідних даних, доцільно створити невелику добірку ікон, які у подальшому можна використовувати у якості еталонів якості та, відповідно, вартості.

Наведемо приклади номенклатурного визначення якості та розрахунків прогнозної вартості двох хатніх ікон: української та російської іконописних шкіл.

До експертної оцінки представлено невелику хатню ікону «Умілєніє Рублево» (рис.4), написану натуральними фарбниками на дошці 3 ковчегом (розміри: 22,5 х 26,2 см (кіот: 16,5 х 18,0 см). На жовто-коричневому фоні в центральній частині ікони погрудне зображення Богородиці Замилування, одягненої в червоний мафорій із золотавими облямівками Божа Матір на правиці тримає Богонемовля в жовто-золотавому хітоні із зеленим клавом, який обнімає Богородицю, притуляючись до неї щічкою. Навколо святих образів окреслено німби, в лівому та правому верхньому куті ікони монограми Богородиці: МР ОУ, нижче праворуч монограма Iсуса Христа: «IC XC». Ікона 
окреслена по краю червоною та синьою смугами. Дерев'яна основа закріплена від вигинання за допомогою двох шпуг, розміщених на зворотній стороні ${ }^{[19]}$. Ікона має товстий, до 0,8 мм., шар левкасу ясно сірого кольору, на який нанесено тонкий шар лесированої фарби (темпера). Поверхневе лакування відсутнє. Окремі деталі, символи та написи нанесені позолотою. Добре проглядаються дві системи кракелюрів. Перша пов'язана з структурою дерева (віддзеркалює структуру дерева, яка змінюється в результаті тривалого всихання) й виражена на поверхні левкасу. Друга, спостерігається під бінокулярним мікроскопом (збільшення 20-30 крат) й пов'язана з старінням тонкого шару напівпрозорих фарб. Розущільнення пов'язані з кракелюрами, заповненими воскоподібними речовинами, що вказує на делікатне чищення поверхні артефакту. Напис «Умілєніє Рублево», виконано старослов'янським письмом й може розглядатися як свідчення про причетність ікони до копіювальних робіт з автентичної ікони відомого іконописця Андрія Рубльова «Богородиця Володимирівська» (1406 р.) [20]. Загальний стан збереження ікони визначається як «задовільний».

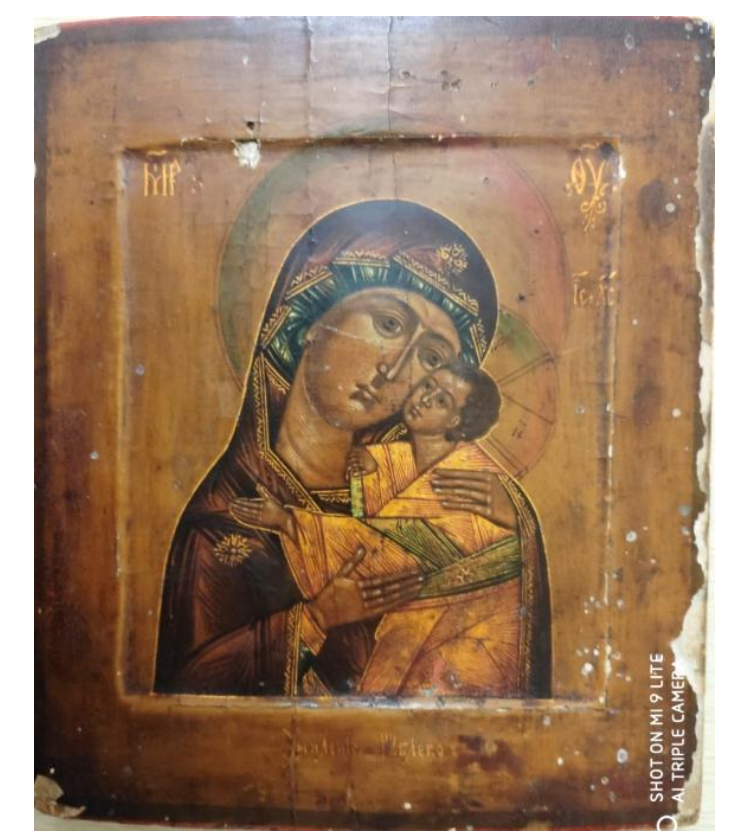

Рис.4. Ікона «Богородиця Замилування» («Умілєніс Рублево»). Росія, Мстера, кінець XVII - початок XVIII століття. Дошка, темпера, левкас. 22,5 x 26,2 cм (кіот: 16,5 18,0 см) / Приватна збірка

За техніко-технологічними ознаками та ознакою дзеркальної інверсії зображення, ікона має бути віднесеною до відомої на національному рівні 
школи майстрів 3 мануфактур селища Мстера (Володимирська область, Росія) [21-22], адже їх ідентифікаційними ознаками є тонкий лаковий живопис по левкасу, використання брунатних та брунатно-червоних пігментів та їх відтінків на тлі ікони, чітко виражені границі елементів зображення, делікатне прописування німбів.

За технологічними ознаками та особливостями написання вік ікони доцільно визначити як кінець XVII - початок XVIII століття. Можна припустити, що в мануфактурі Мстери за цим образом, представленим на експертизу, писали ікони Богородиці на продаж для загального розповсюдження.

Прогнозування вартості цього твору сакрального живопису, згідно описаного вище алгоритму, здійснюємо таким чином. Спочатку вносимо відповідні облікові інформаційні дані у протокол (таблиця 1). В результаті обліку наявної інформації, ми отримали показник соціокультурної значимості пам'ятки - 256 (таблиця 2). Це означає, що номенклатурне визначення якості ікони таке: «Пам'ятка культури національного рівня значення другого порядку».

Прогнозна вартість ікони, без врахування показника ліквідності (показник ліквідності-0,5), становитиме:

$$
\mathrm{C}=57,28 \times 2^{\mathrm{i}} \times \mathrm{S}=57,28 \times 256 \times 2,25 \times 2,62=86442,39 \text { гривень. }
$$

За даними Національного банку України станом на 23.03.2020 року сума 86442,39 гривень складає 3116,16 доларів США. Слід також врахувати, що при наявності відомостей про іконописця чи іншої корисної інформації, показник може збільшуватися (або зменшуватися). Отже, у разі продажу, слід очікувати остаточну вартість більшою ніж поточна, однак, якщо кількість учасників різко скоротиться, торги можуть закінчитися й на названому вище рівні вартості.

Проведена експертна оцінка невеликої хатньої ікони «Святий Пантелеймон» (рис.5), написаної олійними фарбами на дошці з тонким шаром левкасу (розміри: 24 х 17 см.

На блакитному фоні поясне зображення святого мученика та цілителя Пантелеймона [23] у вигляді молодого хлопця з короткою зачіскою, хвилястим темним волоссям, блакитними очима, прямим носом. Святий одягнений в зелену туніка із золотавими облямівками, поверх якої червоний гіматій. 


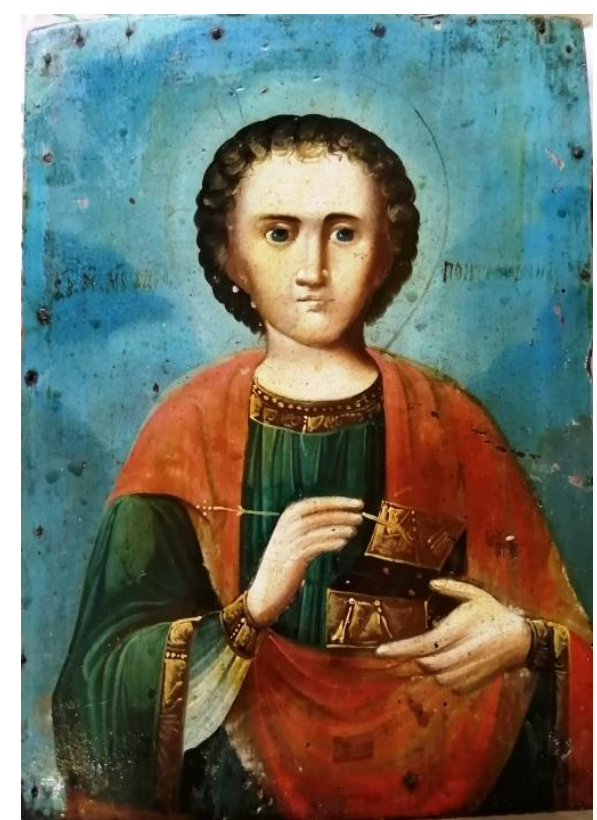

Рис.5. Ікона «Святий Пантелеймон». Украйна, с. Борисівка, кін. ХІХ-поч. ХХст. Дочка, олія; 24 × 17 см. / Приватна збірка

В лівій руці тримає відкритий ларець, в правиці - стилізовану ложечку для ліків. Навколо голови окреслений німб, ліворуч напис: «СВ.Вл.Му.Цел.»; праворуч: «ПОНТЄЛИМОНЪ». У верхній частині ікони вмонтоване кріплення для підвішування на стіну у вигляді металевого кільця.

За техніко-технологічними ознаками встановлено, що ікона реставрована, по краях - втрати фарбового шару та цвяхи, дошка нерівно обрізана. Також технологічні та іконографічні дослідження вказали, що ікона виконана невідомим іконописцем селища Борисівка (Україна) наприкінці XIX - початку $\mathrm{XX}$ ст. «Борисівські» ікони здобули популярність завдяки оригінальності техніки іконопису, декору та іконографічному трактуванню. 3 середині XIX ст. в Борисівці (Одеська обл.) працювали іконописці- «красочники» та іконописці«личкуни». «Красочники» малювали ікону повністю, одяг, фон, а «личкуни» малювали лише обличчя, руки та інколи ноги. Створені майстрами образи вирізнялися красномовністю сюжетів, простотою малюнку та композиції, лінійним трактуванням постатей. Наприкінці XIX ст. у іконописних майстернях слободи працювало приблизно 500 малярів. Ікони Борисівського осередку здобули популярності та поширення як в Україні, так і на Кубані, Кавказі, Болгарії, Сербії ${ }^{[24]}$. Борисівський іконописний промисел вважається унікальним художнім явищем української культури. Останні два десятиліття борисівські ікони привертають особливу увагу як науковців, та колекціонерів. 
В результаті обліку наявної інформації, ми отримали показник соціокультурної значимості пам'ятки - 128 (табл. 2). Це означає, що номенклатурне визначення якості ікони таке: «Пам’ятка культури національного рівня значення другого порядку».

Прогнозна вартість ікони, без врахування показника ліквідності (показник ліквідності-0,5), становитиме:

$$
\mathrm{C}=57,28 \times 2^{\mathrm{i}} \times \mathrm{S}=57,28 \times 128 \times 2,4 \times 1,7=29913,90 \text { гривень. }
$$

За даними Національного банку України станом на 23.03.2020 року сума 29913,90 гривень становить 1078,36 доларів США.

Висновки та перспективи подальших досліджень. За результатами досліджень встановлено, що в основі формування уявлень про якість лежать гуманітарні потреби особистості в справлянні соціокультурних обрядів «причастя-відлучення» та «обдаровування-віддаровування». Водночас, в основі формування цінових покажчиків на ринку, головне значення відіграють фінансові можливості потенційного покупця.

Номенклатурне визначення якості ікон встановлюється на основі врахування сукупності корисної інформації про них, яку обліковують за допомогою відповідей на критеріальні запитання, описані в спеціальному протоколі.

Прогнозовані показники вартості потрібні для визначення можливих фінансових збитків у разі втрати пам'ятки культури або наявності майнових спорів; як орієнтовні показники можливої ринкової вартості (за умови наявності попиту) або показники в фінансових операціях - страхові суми, вартість застави, вартість оренди та інше.

Прогнозування вартості не можна здійснювати за кінцевими результатами аукціонних торгів споріднених предметів, адже у цьому випадку рефлекторно враховується невмотивована компонента, пов'язана 3 індивідуальними суб'єктивними потребами покупців.

За участі в аукціонних торгах важливим фактором успіху слід вважати швидкий вихід предмета до рівня першої кваліметричної точки. Активність учасників ринку в цьому інтервалі дозволяє більш грунтовно передбачити результати у межах перша-друга кваліметрична точка. 


\section{Список використаних джерел}

1. Індутний В.В. Оцінка пам'яток культури. Київ, СПД Моляр С.В., 2009. 537 с.

2. Откович В., Пилипюк В. Українська ікона XIV- XVIII ст. Львів, «Світло й Тінь», 2008. $100 \mathrm{c}$.

3. Евсеева Л., Комашко Н., Красилин М. и др. История иконописи VI - XX века. М. АРТ-БМБ. 2002. 287 c.

4. Панкеев И. Пресвятая Богородица. М.; ОЛМА-ПРЕСС. 2001. 240 с.

5. Степовик Д. Історія української ікони Х-XX ст. К.:Либідь, 2004. 442 с.

6. Шулика В. Иконописные центры Слободской Украины середины XIX-начала XX в. / Теорія і практика матеріально-художньої культури. 2007. С. 119.

7. Скоп Л. Українське церковне малярство в Галичині: техніка та технологія XVXVIII ст. Дрогобич: Коло, 2013. 182 с.

8. Музей волинської ікони: книга-альбом. Александрович В., Василевська С. К.: АДЕФ-Україна, 2016. 400 с.

9. Народна ікона Чернігівщини. Львів: Інститут колекціонерства мистецьких памяток при НТШ, 2015. 424 с.

10. Рижова О. Іконопис Києво-Печерської лаври кін. XVII-початку XIX ст.:

особливості формування та розвитку стилю й іконографії. Культура і сучасність. № 1 (2014). URL: http://journals.uran.ua/kis/article/view/148272.

11. Індутний В. Оцінка пам’яток культури. Київ, СПД Моляр С.В., 2009. 537 с.

12. Індутний В. Застосування функції розподілу Лоренца в товарознавстві. Товари $i$ ринки. 2015. 2 (20). С. 168-178.

13. Індутний В.Формула Р. Хартлі та прогнозування вартості пам'яток культури. Альманах «Культура i сучасність» Національна академія керівних кадрів культури i мистецтв. 2014. №12. С.70-78.

14. Індутний В., Мережко Н., Тоїчкін Д. Товарознавча характеристика антикварної холодної зброї на ринку України. Інститут історії України НАН України, національний музей історії України, Національний військово-історичний музей України, Історія давньої зброї. Дослідження 2016, Київ 2017. С.323-337.

15. Індутний В., Мережко Н., Калуга Н. Товарознавча оцінка антикварних монет на ринку України. Технічні науки та технологї: науковий журнал, Чернігів. 2017. №4(10). С.163-170.

16. Індутний В.,Мережко Н., Піркович К. Аналіз якості і вартості антикварних декоративно-ужиткових й мистецьких творів з бронзи на ринку України. Полтавський Університет економіки і торгівлі. Актуальні проблеми теорії і практики експертизи товарів. Матеріали IV міжнародної науково-практичної інтернет конференції. М.Полтава 20-22 березня 2017 р. С.340-344.

17. Індутний В.В., Мережко Н.В., Золотарьова О.Г. Товарознавча оцінка та загальна класифікація предметів розкоші. Товарознавчий вісник .2020. Випуск 13. С. 108-120.

18. Кассандров О.Н., Лебедев В.В. Обработка результатов наблюдений. М.: Наука. 1970. $200 \mathrm{c}$. 
19. Митна енциклопедія : у 2 т. / І. Г. Бережнюк. Хм.: ПП Мельник А. А., 2013. Том 1. $307 \mathrm{c}$.

20. Лазарев В. Н. Андрей Рублёв и его школа. М., 1966. 100 с.

21. Коромыслов Б. И. Мстёра. М.: Планета, 1970. 48 с. (Народные художественные промыслы).

22. Дмитриев Н. Г. Мстёра рукотворная: Рассказы об искусстве лаковой миниатюры и её мастерах. Л.: Художник РСФСР, 1986. 438 с.

23. Життя i страждання Святого Великомученика i Цілителя Пантелеймона. Коломийська єпархія. URL: https/kolomij.com/zhittya-svyati.

24. Українська історія «борисівської» ікони. URL: https://honchar.org.ua/p/ukrajinskaistoriya-borysivskoji-ikony.

\section{Reference}

1. Indutnyi V.V.(2009). Otsinka pamiatok kultury [Assessment of cultural monuments]. Kyiv, SPD Moliar S.V., 2009. 537c.

2. Otkovych V., Pylypiuk V.(2008). Ukrainska ikona XIV- XVIII st. [Ukrainian icon of the XIV-XVIII centuries]. Lviv. Svitlo y Tin. $100 \mathrm{~s}$.

3. Evseeva L, Komashko N., Krasylyn M. (2002). Ystoryia ykonopysy VI - XX veka [History of icon painting of the $6^{\text {th }}-20^{\text {th }}$ centuries]. M. ART-BMB. 2002. $287 \mathrm{~s}$.

4. Pankeev Y.(2001). Presviataia Bohorodytsa [Holy Mother of God]. M.; OLMA-PRESS. 2001. $240 \mathrm{~s}$.

5. Stepovyk D.(2004). Istoriia ukrainskoi ikony X-XX st.[ History of the Ukrainian icon of the X-XX centuries]. K.:Lybid, 2004. 442 s.

6. Shulyka V.(2007). Ykonopysnie tsentri Slobodskoi Ukrayni seredyni XIX-nachala XX [

Icon-painting centers of Sloboda Ukraine in the middle of the XIX-beginning of the XX century. / Theory and practice of material and artistic culture]. Teoriia i praktyka materialnokhudozhnoi kultury. 2007. S. 119.

7. Skop L.(2013). Ukrainske tserkovne maliarstvo v Halychyni: tekhnika ta tekhnolohiia XVXVIII st. [Ukrainian church painting in Galicia: technique and technology of the XV-XVIII centuries.] Drohobych: Kolo, 2013. 182 s.

8. Muzei volynskoi ikony: knyha-albom [Museum of the Volyn Icon: book-album]. Aleksandrovych V., Vasylevska S. K.: ADEF-Ukraina, 2016. $400 \mathrm{~s}$.

9. Narodna ikona Chernihivshcheny [People's icon of Chernihiv region]. Lviv: Instytut kolektsionerstva ukainskykh mystetskykh pamiatok pry NTSh, 2015. $424 \mathrm{~s}$.

10. Ryzhova O. Ikonopys Kyievo-Pecherskoi lavry kin. KhVII-pochatku KhIKh st.: osoblyvosti formuvannia ta rozvytku styliu y ikonohrafii [Icon painting of the Kiev-Pechersk Lavra kin. XVII-early XIX centuries: features of formation and development of style and iconography]. Kultura i suchasnist. № 1 (2014). URL: http://journals.uran.ua/kis/article/view/148272.

11. Indutnyi V. Otsinka pamiatok kultury [Formula R. Hartley and forecasting the value of cultural monuments]. Kyiv, SPD Moliar S.V., 2009. 537 s. 
12. Indutnyi V. (2015). Zastosuvannia funktsii rozpodilu Lorentsa v tovaroznavstvi [Application of the Lorentz distribution function in commodity science]. Tovary $i$ rynky. 2 (20). 2015. S. 168-178.

13. Indutnyi V. (2014). Formula R. Khartli ta prohnozuvannia vartosti pam'iatok kultury [Formula R. Hartley and forecasting the value of cultural monuments]. Almanakh «Kultura $i$ suchasnist» Natsionalna akademiia kerivnykh kadriv kultury i mystetstv. №12. S.70-78.

14. Indutnyi V., Merezhko N., Toichkin D.(2017). Tovaroznavcha kharakterystyka antykvarnoi kholodnoi zbroi na rynku Ukrainy. Instytut istorii Ukrainy NAN Ukrainy, natsionalnyi muzei istorii Ukrainy, Natsionalnyi viiskovo-istorychnyi muzei Ukrainy, Naukovi pratsi. «Istoriia davnoi zbroi» Doslidzhennia [Commodity characteristics of antique melee weapons on the Ukrainian market. Institute of History of Ukraine, National Academy of Sciences of Ukraine, National Museum of History of Ukraine, National Military History Museum of Ukraine, History of Ancient Weapons. Research].2016, Kyiv 2017. S.323-337.

15. Indutnyi V., Merezhko N., Kaluha N. (2017). Tovaroznavcha otsinka antykvarnykh monet na rynku Ukrainy [Commodity assessment of antique coins on the market of Ukraine]. Tekhnichni nauky ta tekhnolohii: naukovyi zhurnal, Chernihiv. 2017. №4(10). S.163-170.

16. Indutnyi V.,Merezhko N., Pirkovych K. (2017). Analiz yakosti i vartosti antykvarnykh dekoratyvno-uzhytkovykh y mystetskykh tvoriv z bronzy na rynku Ukrainy. Poltavskyi Universytet ekonomiky i torhivli. Aktualni problemy teorii i praktyky ekspertyzy tovariv. Materialy IV mizhnarodnoi naukovo-praktychnoi internet konferentsii. Poltava 20-22 bereznia 2017. [Analysis of the quality and value of antique decorative and applied and artistic works of bronze on the market of Ukraine. Poltava University of Economics and Trade. Actual problems of the theory and practice of examination of goods. Proceedings of the IV International Scientific and Practical Internet Conference.]S.340-344.

17. Indutnyi V.V., Merezhko N.V., Zolotarova O.H. (2020). Tovaroznavcha otsinka ta zahalna klasyfikatsiia predmetiv rozkoshi [Commodity assessment and general classification of luxury items]. Tovaroznavchyi visnyk LNTU. 2020. Vypusk 13. S. 108-120.

18. Kassandrov O.N., Lebedev V.V. (1970). Obrabotka rezultatov nabliudenyi [Processing of observation results]. M.: Nauka. 1970. $200 \mathrm{~s}$.

19. Berezhniuk I. H. (2013). Mytna entsyklopediia [Customs encyclopedia]: u 2 t. / (vidp. Red.) ta in. Khm.: PP Melnyk A. A., 2013. Tom 1. 307c.

20. Lazarev V. N.(1966). Andrei Rublëv y eho shkola [Andrei Rublev and his school]. M., 1966. $100 \mathrm{~s}$.

21. Koromuslov B. Y.(1970). Mstëra [Mstyora]. M.: Planeta, 1970. 48 s.

22. Dmytryev N. H.(1986). Mstëra rukotvornaia: Rasskaz ob yskusstve lakovoi mynyatiur y eë masterakh . Leningrad. Khudozhnyk RSFSR, 1986. $438 \mathrm{~s}$.

23. Zhyttia i strazhdannia Sviatoho Velykomuchenyka i Tsilytelia Panteleimona. Kolomyiska yeparkhiia [Life and suffering of the Holy Great Martyr and Healer Panteleimon. Kolomyia diocese]. URL: https/kolomij.com/zhittya-svyati.

24. Ukrainska istoriia «borysivskoi» ikony [Ukrainian history of the "Borisov" icon]. URL: https://honchar.org.ua/p/ukrajinska-istoriya-borysivskoji-ikony. 
Goal. A description of one of the possible ways to assess the quality and forecast the value of iconographic works, as well as a description of examples of such assessment, which are valid results of research on the market of the goods.

Method. To achieve the goal, methods of protocol comparative analysis of samples to be evaluated with individual objects selected in the related objects system, which have already been evaluated and presented on the open market, were used. Thus, the requirements for validity, reproducibility and availability for forecasting results verification, as well as their correction in the presence of changes in the antique and art markets are achieved.

Results. According to the research results, it is established that the basis of the formation of ideas about quality are the humanitarian needs of the individual in the socio-cultural rites of "communion-excommunication" and "gifting-gifting". At the same time, as the basis of the price indicators formation in the market, the main importance is played by the financial capabilities of the potential buyer. Nomenclature definition of the icons quality is established on the basis of a useful information set about them, which is taken into account by answering the criterion questions described in a special protocol. Estimated values of icons are needed to determine possible financial losses in the event of a cultural values loss or property disputes; as indicative indicators of possible market value (provided there is demand) or indicators in financial transactions insurance amounts, the value of collateral, rent and more. Price forecasting cannot be based on the related items auctions final results, as in this case the unmotivated component related to the individual subjective needs of buyers is reflexively taken into account. When participating in auction bidding, an important success factor should be considered the rapid exit of the subject to the first qualimetric point level. The activity of market participants in this interval allows you to more thoroughly predict the results within the first or second qualimetric point.

Scientific novelty. The optimal method of the icons value forecasting to meet the needs of professional appraisers in determining the financial losses level due to the loss of a cultural values (or partial loss), justification of insurance amounts, book value, expected value when selling on the open market, and also in operations of rent, pledge, estimation of ownerless property.

Practical importance. The research of the icons modern market is carried out, the basic factors of ideas formation on their quality are allocated and theoretical commodity bases for realization of the quality estimation and cost forecasting are developed. These developments are of high practical importance: they will contribute to the preservation of this group of artistic and historical valueables and the relevant knowledge introduction in the field of culture, national upbringing and education.

Keywords: iconography, icon, estimated value, saleability ratio.

Стаття рекомендована до друку доктором технічних наук, професором КНТЕУ Мережко Н.В. дата надходження статті в редакиію 02.02.2021 p. 